OPEN ACCESS

Edited by:

Mario Barletta

Universidade Federal de Pernambuco

(UFPE), Brazi

Reviewed by:

Jin-Hyoung Kim,

Korea Polar Research Institute,

South Korea

Markus Frederich,

University of New England,

United States

Gabriel Machovsky-Capuska,

University of Sydney, Australia

*Correspondence:

Simon A. Morley

smor@bas.ac.uk

Specialty section:

This article was submitted to Marine Conservation and

Sustainability,

a section of the journal

Frontiers in Marine Science

Received: 06 November 2018 Accepted: 19 December 2018

Published: 17 January 2019

Citation:

Morley SA, Barnes DKA and Dunn MJ (2019) Predicting Which Species Succeed in Climate-Forced Polar

Seas. Front. Mar. Sci. 5:507. doi: 10.3389/fmars.2018.00507

\section{Predicting Which Species Succeed in Climate-Forced Polar Seas}

\author{
Simon A. Morley*, David K. A. Barnes and Michael J. Dunn \\ British Antarctic Survey, Natural Environment Research Council, Cambridge, United Kingdom
}

Understanding the mechanisms which determine the capacity of any species to adapt to changing environmental conditions is one of the foremost requirements in accurately predicting which populations, species and clades are likely to survive ongoing, rapid climate change. The polar oceans are amongst the most rapidly changing environments on Earth with reduced regional sea ice duration and extent, and their fauna's expected sensitivity to warming and acidification. These changes potentially pose a significant threat to a number of polar fauna. There is, therefore, a critical need to assess the vulnerability of a wide range of species to determine the tipping points or weak links in marine assemblages. Knowledge of the effect of multiple stressors on polar marine fauna has advanced over the last 40 years, but there are still many data gaps. This study applies ecological risk assessment techniques to the increasing knowledge of polar species' physiological capacities to identify their exposure to climate change and their vulnerability to this exposure. This relatively rapid, semi-quantitative assessment provides a layer of vulnerability on top of climate envelope models, until such times as more extensive physiological data sets can be produced. The risk assessment identified more species that are likely to benefit from the near-future predicted change (the winners), especially predators and deposit feeders. Fewer species were scored at risk (the losers), although animals that feed on krill scored consistently as under the highest risk.

Keywords: climate change, ecological risk assessment, vulnerability, physiological niche, sea ice, food webs

\section{INTRODUCTION}

Amongst the foremost scientific questions of the Anthropocene are which populations, species and clades will survive sustained, rapid climate change and which mechanisms underpin their sensitivity (Pennisi, 2005). Previous mass extinctions have led to massive faunal shifts whereby $5-29 \%$ of the original species dominate the remaining fauna, leading to a global "biotic homogenization" (McKinney and Lockwood, 1999). Likewise current impacts seem to be following a "few winners, many losers" pattern, with most of Earth's monitored species showing large scale declines (70\% of global bird species; Collar et al., 1994), but with some taxa, such as ducks (Anatidae) and grasses (Poacae), increasing and thus more likely to be over-represented in future patterns of biodiversity. The species that tend to dominate after such extinctions share features of high genetic and/or physiological diversity, broad geographic ranges, high dispersal, broad capacities and tolerances (eurytopic species), small body sizes, high fecundity, and, in the Anthropocene, a positive association with human societies (McKinney and Lockwood, 1999). Currently the most intense and rapid climate forcing has occurred in parts of Earth's high latitudes, many of whose fauna have few of those typical "winner" features. 
The polar regions, particularly the Southern Ocean and Antarctica, have had comparatively little direct human impact on their biota. In the previous century there was a drastic overexploitation of fish, seals and whales, which has led to some dramatic disruption of higher trophic levels (Miller, 1991). What we know of the fauna from the Southern Ocean continental shelf suggests they share many of the traits, identified by McKinney and Lockwood (1999), which make them more likely to be losers rather than winners. The rich biota there show high levels of endemism, ranging from $37 \%$ in hexacorals to $70 \%$ in gastropods (De Broyer et al., 2014) and therefore generally have restricted geographic ranges. Growth in cold water is slow and many ectotherms have long life spans and long generation times, which act to reduce the chances for adaptive change (Peck, 2011). Many Antarctic ectotherms have also evolved specific adaptations to cope with life in the Southern Ocean, such as antifreeze proteins (DeVries, 1971) and lack of hemoglobin (Ruud, 1954), which give them narrow tolerance ranges; they are classically stenotopic. Body size spectra vary considerably with clade (small in mollusks Hain and Arnaud, 1992, large in amphipods Chapelle and Peck, 1996) but fecundity is typically low (Pearse et al., 1991).

The physiological and biological capacity of all animals and plants has evolved to cope with their experienced environmental variability (e.g., Clarke and Crame, 1992). The Southern Ocean is one of the most constant surface environments in terms of annual temperature and salinity range but one of the most variable in terms of photoperiod, disturbance and phytoplankton abundance (so food availability for secondary production) (Clarke, 1988). This physical environment, although relatively constant for more than 4 million years, nevertheless has regular massive perturbations in the form of glaciation cycles (driven by variations in the Earth's orbit, with 41 and 101 kyr cyclicity). Glaciations have varied in magnitude and duration but in each the expansion and contraction of grounded ice sheets has changed the size and geography of continental shelves drastically (as grounded ice covers much of the continental shelves). Thus life in the Southern Ocean has experienced considerable past stresses, within interglacial periods (e.g., warming, freshening, sedimentation and iceberg disturbance) but especially in transitions to and from glaciation. The impact of modern and near future change has to be set against the backdrop of those historic "norms" of stress and resultant habitat shifts.

Modern change is mainly driven by increasing atmospheric $\mathrm{CO}_{2}$ and other "greenhouse" gas emissions but also ozone depleting chemicals. Salinities, UV irradiation and wind patterns have already begun to alter in the Southern Ocean and sea temperature (IPCC, 2013) and $p \mathrm{H}$ are predicted to change considerably (Orr et al., 2005). Aragonite saturation may become one of the biggest stresses affecting polar seas, due to lower initial saturation levels and greater dissolution of atmospheric $\mathrm{CO}_{2}$ into cold waters (Gutt et al., 2015). Secondary physical impacts to air temperature and the influx of deeper, warmer water masses have included extensive sea-ice changes, glacier retreat, ice shelf collapses and sea level rise (Cook et al., 2005, 2016). Investigating the effect of multiple stressors on life in the Southern Ocean has been identified as one of the 80 priority questions for future scientific research (Kennicutt et al., 2014). The effect of interaction of such variables on organisms have been little considered to date, but the impacts of some of these stressors have been studied in some detailboth in terms of manipulations and field observations. Most direct experimentation has involved temperature or $p H$. Stresses to organisms in polar regions (and elsewhere) from changing climate are not isolated from other stressors. Their impact occurs in combination with, and can be altered by, other stresses, such as harvesting (fishing), pollution, non-indigenous species (NIS) and habitat alteration. However, compared with elsewhere on Earth these are all minimal, although top predator harvesting has been high in the past, plastic pollution is increasing (Barnes et al., 2018) and the threat of NIS establishment growing.

The Southern Ocean has an important fauna, with massive stocks of krill (Euphausia superba), is home to $99 \%$ of southern polar species and is the only place on Earth left where all the established fauna are native. However, there are more reports of non-native species that could become established, such as decapod crustaceans (Aronson et al., 2015) and mussels (Lee and Chown, 2007), as climate changes. In the near future, it has been suggested that $86 \%$ of the Southern Ocean's area may be impacted by 2-3 overlapping stressors (Gutt et al., 2015). In contrast, there is little evidence of change or a trend in physical change in the ocean around East Antarctica (i.e., the majority of the Southern Ocean). There remains considerable uncertainty and divided opinions on the level of vulnerability of its fauna (Barnes and Peck, 2008). As elsewhere stressors are likely to impact organisms in different ways, for example all marine invertebrates are ectothermic, whilst all marine mammals and birds are endothermic. As such, they will experience different types of stress within the Southern Ocean, the magnitude of which will vary as the environment changes. Ectotherm physiology is more directly affected by the physical environment, such as temperature and ocean acidification (OA). The environment will have less of a direct effect on endotherms but more of a cascading effect through impacts on food webs. However, several polar endotherms give birth on sea ice, feed through sea ice, or utilize sea ice to haul out for periods of rest. The many organism types and species directly associated with sea ice are likely to be amongst those which will lose out most to sustained climate change.

Polar ecosystems are often considered simpler than those at lower latitude and certainly have less direct anthropogenic stressors. However, even in the Southern Ocean the complexity of ecosystems means that it is only possible to have a partial understanding of all the interactions between environment and species. This in turn limits our ability to determine the structure and stability of the food web and nutrient cycles. In these data-deficient situations managers need to use tools that allow vulnerability to be assessed. Risk Assessment is a formal process of identifying the hazards, or risks, identifying the extent of the exposure (exposure assessment), the sensitivity to that risk (doseresponse assessment), and where possible, suggesting measures to manage or mitigate that risk (Karr and Chu, 1997). While this is a standard procedure to ensure human health in the work place, the risk assessment framework is increasingly being applied to ecological systems (Karr and Chu, 1997; Holsman et al., 2017) 
TABLE 1 | Description of climate risk factors.

\begin{tabular}{ll}
\hline Ocean acidification & $\begin{array}{l}\text { The reduction of } \mathrm{pH} \text { of the ocean caused primarily by } \\
\text { the uptake of atmospheric } \mathrm{CO}_{2} .\end{array}$ \\
Sea ice & The reduction in the duration and extent of sea ice. \\
Temperature & Warming of the ocean. \\
Ice scour & The increase in the frequency of iceberg impacts on \\
the sea floor. & The break-up of sheets of floating ice that are \\
lce shelf collapse & permanently attached to a land mass \\
Sediment & $\begin{array}{l}\text { The increase in sedimentation of glacial flour (ground } \\
\text { rock) } \\
\text { Tlacial retreat }\end{array}$ \\
Snowfall & Precipitation as snow that covers the land
\end{tabular}

to assess which risks will cause maximum disruption to the ecosystem or have the greatest socio-economic impact. The level of complexity that can be included in ecological risk assessments will vary depending on data availability. In the best described environments detailed approaches, such as the NatureServe Climate Change Vulnerability Index (Young et al., 2015), can be employed. In data-deficient ecosystems, expert opinion can provide qualitative assessments of relative risk, allowing rapid, but crude, assessments to be made (Holsman et al., 2017). These may be sufficient to determine priorities for further monitoring or data collection efforts.

This study aims to combine advances in ecological risk assessment with improved data availability for exposure and vulnerability to climate change of Antarctic marine animals. Here we risk assess which Southern Ocean species are likely to be most and least impacted, using model forecast projections of climate change and what is currently known of organismal responses to physical change to date. In this way we identify the exposure to climate change risk and combine this with vulnerability to that exposure to build a risk assessment matrix that will help define priorities for future research and management actions.

\section{MATERIALS AND METHODS}

The risk assessment was conducted in two stages. First, there was a comprehensive meta-analysis of the literature from which the environmental factors that determine risk exposure of Antarctic marine fauna were extracted. We reviewed how these factors are projected to alter through the effects of climate change on the Antarctic near shore marine environment. This information was then used to assess the positive and negative effects of each of these stressors to individual species.

\section{Literature Review}

A comprehensive search of the literature was conducted to identify the current state of knowledge of the risks to Antarctic marine fauna and how these risks are predicted to change. These factors included environmental factors that are already in flux and/or are projected to change with climate (Table 1). The literature review also took into account some of the drivers underlying these factors, such as the link between the ozone hole and strengthening winds.
TABLE 2 | Scoring of expected species response to change based on the literature review.

\begin{tabular}{cl}
\hline Score & Prediction \\
\hline+2 & 2 positive responses to change \\
+1 & 1 positive response to change \\
0 & No response \\
-1 & 1 negative response to change \\
-2 & 2 negative responses to change \\
N/A & Not applicable \\
& Blank cells indicate the effect is not known
\end{tabular}

\section{Risk Assessment}

From the literature meta-analysis, it was determined that advances in knowledge of the vulnerability to climate change exposure, a semi-quantitative rank-based exposure-sensitivity assessment could be applied to Antarctic marine fauna. We applied the level 2 risk assessment of Holsman et al. (2017), which aims to identify the highest risk components of the ecosystem that can then be prioritized for more detailed analyses.

Literature that provided experimental evidence of responses to risk factors was used to score the risk. A positive $(+1)$, negative $(-1)$ or no expected response $(0)$ was scored for each risk factor for which there was available literature (Table 2). So, a score of +2 indicates that there was literature evidence for two positive responses to the predicted change in that factor. These scores were summed for each species to predict the total risk for each species.

Due to their long generation times, many polar marine ectotherms have low adaptive potential (Peck, 2011), which is therefore excluded from this analysis. Due to fundamental differences in vulnerability we consider ectotherms and endotherms separately. For the marine endotherms, sufficient information is known about the key components of their diet. It was therefore possible to estimate not only the direct risk of exposure to climate change, but the indirect effects through the food web as well. These direct and indirect scores were summed to create the final assessment.

\section{RESULTS}

\section{Literature Review: Defining Risk Exposure and Vulnerability to Climate Change Temperature}

To date marine temperature rises have only been associated with the shallowest 20 meters of the Bellingshausen and Scotia seas (Meredith and King, 2005). In general, therefore, species most likely to be at risk are those with geographic ranges restricted to shallow shelf depths in this region and with narrow temperature envelopes. Many Antarctic marine ectotherms are considered "stenothermal," with many recorded to have poor capacity to cope with even modest increases in temperature (Pörtner, 2002). Small rises in temperature can drive increased growth of some species, but performance gains are no longer clear with 
even as little as a $2^{\circ} \mathrm{C}$ rise above ambient sea temperatures (Ashton et al., 2017).

Temperature rise has been widely considered to be one of the greatest risks to Antarctic marine ectotherms, as they have been shown to have long term lethal temperature limits and limits for activity only $0-5^{\circ} \mathrm{C}$ above currently experienced maximum environmental temperature (Peck et al., 2014). Whilst global air temperature increases have dramatically slowed or even halted in recent years, future warming of the ocean (Smith, 2016) and the atmosphere (IPCC, 2013) is predicted. Climate envelope models, based on species distributions and their currently experienced annual temperature ranges, were combined with projected warming to predict how species ranges will shift (Griffiths et al., 2017). However, while climate envelope models give a measure of exposure, they need to be overlain by a layer of vulnerability based on known physiological tolerance. While many of the species living in the shallow Antarctic are eurybathic, with distributions that stretch well below these surface waters, their population densities are often at their highest in the shallowest $20 \mathrm{~m}$, e.g., the limpet, Nacella concinna, the urchin, Sterechinus neumayeri and the sea cucumber, Heterocucumis steineni. In unusually calm conditions the temperature of the surface $5 \mathrm{~m}$ of the ocean have been recorded to reach $4^{\circ} \mathrm{C}$ (Morley pers obs.), a temperature that is above the thermal limit for several critical physiological functions of $N$. concinna (Peck et al., 2004; Morley et al., 2012). So, whilst individuals living in deeper water are unlikely to be affected by surface warming, the vast majority of the populations of these shallow water species will. These are all hugely abundant species in the shallow Antarctic ecosystem, so even if their populations can persist in the face of surface warming, any reduction in numbers in the shallows is likely to have major impacts through these food webs. However, marine warming has other indirect effects, such as reduction of sea ice, melting of ice shelves and lubricating the underside of glaciers, as well as reducing the duration of "winter" (Barnes, 2017a). Reduction of sea ice and the period of time when the sea is at freezing temperatures could both lead to increased light penetration into surface waters and therefore increased primary productivity (Barnes, 2015) amongst other effects.

\section{pH}

As in other oceans, gases dissolve into and out from the Southern Ocean in equilibrium with partial pressures in the atmosphere above them. Increased atmospheric $\mathrm{CO}_{2}$ concentrations have driven small and large net absorptions in the Southern and Arctic Oceans respectively (Sabine et al., 2004). These lower $p H$, causing $\mathrm{OA}$, are predicted to have one of the major anthropogenic impacts on marine species, particularly those that rely on synthesizing calcified exoskeletons (Bray et al., 2014). As liquids can hold more gas with lowered temperature, it was thought that polar ocean fauna would be more impacted by OA than in other oceans (Guinotte and Fabry, 2008). However, recent studies have shown that the $p H$ of the seas off the Western Antarctic Peninsula (WAP) have not (yet) acidified rapidly, and have a high spatial and temporal variation from $p H$ 7.6-8.3 (Bjork et al., 2014; Collard et al., 2015). With large seasonal variation in the pattern of deep $\mathrm{CO}_{2}$-rich water upwelling to the surface of the Southern Ocean (Takahashi et al., 2009), marine animals may therefore have evolved the flexibility to cope with this high level of variability in their environment (Suckling et al., 2015; Morley et al., 2016).

There have been concerns that reduced ability to synthesize carbonate (particularly aragonitic) shells might leave some species vulnerable to predators. There are few durophagous (crushing) predators in the Southern Ocean, and only in a few locations are they abundant, but despite some high impact opinion-based science reports and popular headlines, there is little or no evidence to support any increased predation response to date (Griffiths et al., 2013). The strongest evidence for OA impacts is on thinly shelled, pelagic pteropod mollusks (Bednaršek et al., 2012). Although the carbonate compensation depth (CCD) is expected to become shallower, the high eurybathy in Antarctic marine species (compared with lower latitude species) found to date (Brey et al., 1996) shows that populations occur below this horizon already. The Antarctic fauna is still poorly described and new scientific samples from deep shelf and slope depths are still increasing the known bathymetric (and geographic) ranges of species (e.g., bryozoans in Barnes and Kuklinski, 2010). Thus, whilst it is possible that the Southern Ocean may be disproportionately impacted it may also be that much, or even most, of the fauna is fairly robust to this. Perhaps the most important question is how will primary productionphytoplankton (necessarily near surface)—be affected by lowered $p H ?$

\section{Salinity}

The Southern Ocean is a high salinity region and sea surface change-trends are hard to interpret because they are so closely connected to changes in the timing and geography of sea ice formation and melt. Warming can directly drive salinity change through melt waters but also indirectly affect freshening through sea ice increases or reductions. Salinity has changed in the Bellingshausen Sea due to a dramatic reduction in winter sea ice formation, reducing the extent of summer melting. This has led to an increase in summer salinity of surface waters (Meredith and King, 2005). During the second half of the twentieth century the increased precipitation, reduced sea ice production and increased melting of the West Antarctic ice sheet has, conversely, led to a freshening of the surface waters of the Ross Sea (Jacobs et al., 2002). Unlike in the Arctic, Southern Ocean salinity changes have been small and there is little evidence of this being an important near-future stressor to Southern Ocean fauna. The exception to this is near coastal systems (fjords, shores and surface waters) around West Antarctica, as rapidly retreating glaciers pass their grounding lines and melt water flows from under thinning ice shelves (such as Thwaites Glacier).

\section{Ozone Losses Leading to Increased UV and Strengthening Wind}

Use of industrial chlorofluorocarbons during the twentieth century led to a thinning of the ozone layer and the development of a late winter and spring "ozone hole" over the Antarctic (Solomon, 1990). This has had several effects on marine 
animals living in the shallows in the Antarctic Peninsula region. The reduced protection by ozone has led to an increase in exposure to UV-radiation (Karentz and Bosch, 2001). Although UV only penetrates through the first few tens of meters of seawater, it can have damaging effects on marine organisms from phytoplankton through to benthic invertebrates and fish (Karentz and Bosch, 2001). The impact on the atmosphere has also led to strengthening winds that have caused an increase in sea ice in regions of East Antarctica but large losses of sea ice and ice shelves on the WAP (Thompson et al., 2011; Holland and Kwok, 2012). Barnes et al. (2011) hypothesized that the main cause of recent rapid increases in growth by Ross Sea shelf benthos (bryozoans) was increased winds maintaining ice-free areas (polynyas) within the sea ice. Maintaining open water areas in turn increased light and enhanced longer blooms of their phytoplankton food (Arrigo et al., 2008).

\section{Food Availability}

One of the few demonstrable responses to physical change to date has been distributional, timing, duration and compositional changes in phytoplankton productivity (Arrigo et al., 2008). The nature of phytoplankton change seems to be complex and climate-mediated trends remain unclear. If composition does alter from diatom domination to more smaller and naked cells (e.g., ciliates and flagellates), this could enhance growth in primary consumers (such as suspension and deposit feeders). New coastal (highly productive) phytoplankton blooms now occur where glaciers have retreated and ice shelves have collapsed (Peck et al., 2010a). Longer abundances of (phytoplankton) food have also been strongly correlated with sea ice losses and driven widespread increased growth performance of benthos (Barnes et al., 2016). These new and longer blooms have resulted in significant increases of benthic carbon accumulation on the West Antarctic seabed, leading to an important negative feedback on climate change (Barnes, 2015). Whilst marine warming and sea ice losses may sustain increases in phytoplankton availability, $\mathrm{UV}$ increases, $\mathrm{OA}$ and freshening are likely to impact near surface algal species. Altered sea ice patterns are likely to strongly influence assemblages directly linked to (the considerable) seasonal sea-ice algae build-ups. Thus changing food availability is likely to generate quite a number of winners and losers depending on geography-primary consumer winners on shelves underlying ice shelf collapses and major sea ice reductions but losers associated with sea ice algae and associated productivity.

Warming may also act to reduce the duration of the "winter fast" of ectotherms but this is not necessarily positive for all species. The cold winter period may be essential for some Antarctic marine ectotherms, allowing them to use the period of low maintenance metabolic costs to, for example, channel the energy gained through the summer into growth. The brachiopod Liothyrella uva is thought to use all of its physiological capacity to process food during the summer, such that growth can only occur during winter, decoupled from feeding (Peck et al., 1997). In strong contrast other similar (but colonial) suspension feeding animals, such as the bryozoan Cellarinella watersi, undertake growth throughout the summer but cease growth as soon as food is less available (Barnes, 1995). If changes in sea ice duration affect the characteristics of the phytoplankton bloom (Venables et al., 2013), or shorter winters reduce the period of minimum maintenance metabolism, then animals may not gain enough energy during the limited feeding period to survive through the following winter.

\section{Glacier Retreat}

Widespread glacial retreat is perhaps the most directly observed and publicly conscious impact of climate change. The proportion of West Antarctica in retreat has drastically increased, as has the rate of glacial retreat (Cook et al., 2005). The impact of some of these, particularly the Pine Island and Thwaites glaciers, have far-reaching consequences on shelf water masses, sea level rise and even West Antarctic Ice sheet stability (Vaughan et al., 2011). The impacts of such are less well-documented in the Southern Ocean than in the Arctic, although Sahade et al. (2015) detailed strong nearshore ecosystem responses to glacial retreat in Maxwell Bay, King George Island. There they found the resultant sedimentation was the key factor driving assemblage change with losers being suspension feeders, such as the ascidian Molgula pedunculata. In contrast infaunal deposit feeders which were able to persevere with high sediment loading e.g., Laternula elliptica had fewer space and food competitors (e.g., Philipp et al., 2011; Sahade et al., 2015).

\section{Sea Ice Losses and Habitat Availability}

Changes in the seasonal extent of sea ice influence habitat availability, albedo, light availability, primary productivity, abundance and species composition. The duration of the fast ice component (winter sea surface freeze) has an important role in minimizing disturbance through "locking in" icebergs, preventing movement and thereby reducing seabed scour. Remote-sensed imaging suggests that regional sea ice (mainly fast ice) losses are one of the most measurable impacts of climate change at the poles to date. At Ryder Bay, WAP, this has approached 5 days less of fast ice per year for the last 2 decades, strongly inversely correlated with the number of ice scour events on the seabed (Barnes and Souster, 2011). Although sea ice losses lead to higher benthic mortality in the shallows, this is more than compensated for in terms of biomass or zoobenthic carbon stocks by increased growth in deeper water due to longer phytoplankton blooms (Barnes, 2017a). As with most, if not all stressors, changes in seabed scouring levels affect marine species differently; although $99 \%$ of individuals may be killed in a scour event this also provides carrion and opens up new habitat space. Losers from intense scouring are slow growing and slow maturing species like the brachiopod Liothyrella uva, corals and sponges, whereas pioneers, such as polychaete worms, bryozoans and scavengers, such as the nemertean worm Parbolasia corrugatus and echinoderms Odontaster validus and Sterechinus neumayeri benefit. The biggest winners from the combination of sea ice losses and slightly raised temperatures could be macro-algae, through extending their richness, productivity and range further south.

Changes in sea ice duration and extent correlate with population processes of many Southern Ocean species and, in particular, the biomass and distribution of Antarctic krill 
(Euphausia superba), a key species linking primary production to upper-trophic levels (Atkinson et al., 2004; Trathan et al., 2007). Sea ice provides an important habitat for Antarctic krill, the young of which feed on algae growing on the underside of the sea ice. As such the annual change in sea ice duration and extent is a key influence on krill population dynamics, particularly in the WAP region, which is an important spawning ground for this species (Quentin and Ross, 2001; Murphy et al., 2007). Indeed, the loss of sea ice on the WAP led to a $70 \%$ reduction in krill around South Georgia between 1975 and 2003 (Atkinson et al., 2004). It is, however, possible that rather than (krill) reduction, much of the krill biomass is following the changing position of the marginal sea ice zone (whereas the positioning of scientific measurements is more restricted) (Brierley et al., 2002).

Recent studies from a number of sites located across the WAP and Scotia Sea region have provided strong evidence of shifts in the distribution of both Adélie (Pygoscelis adeliae) and chinstrap (Pygoscelis antarctica) penguin populations (Croxall et al., 2002; Dunn et al., 2016). However, the role played by sea ice dynamics in influencing the population trends of uppertrophic predators (both pagophilic and pagophobic) is complex. Recent research has suggested sea ice dynamics play a key role in influencing juvenile over-winter survival in pygoscelid penguins not simply through a direct effect on habitat availability, but rather by influencing the availability of Antarctic krill (Hinke et al., 2007; Lynch et al., 2012). By acting as a mediating link between predators and prey, sea ice can exert a key influence on predator-prey relationships; episodic recruitment levels of krill reflect the temporal variation not only in duration and extent, but also in advance and retreat of sea ice (Quentin and Ross, 2003; Trathan et al., 2007). The relationship between sea-ice conditions and trophic-mediated variability has been reported in long-term studies of population size and breeding success in Antarctic fur seals (Arctocephalus gazella) at South Georgia. These studies have revealed an inverse relationship between breeding success and sea surface temperatures (Forcada et al., 2005, 2008). The increase in positive temperature anomalies associated with increasing ENSO events has increased environmental variability and led to less predictable and limited availability of krill. This has increased the fitness costs of breeding fur seals and led to the loss of life history buffering. However, the role played by sea ice dynamics in influencing the population trends of uppertrophic predators is complex. There is evidence that both greater and lesser winter sea ice extent improved the breeding success of snow petrels (Pagodroma nivea), although adult survival has been strongly correlated with years of extensive sea ice (Croxall et al., 2002).

\section{Ecological Risk Assessment Marine Ectotherms}

Of the 21 species assessed, 15 were predicted to be winners in the face of climate change and 4 scored a neutral summed response. Summed negative responses were only predicted for two species. The species predicted to be at most risk were the amphipod Paracerodocus miersi and the brachiopod Liothyrella uva (Table 3). The species expected to be at least risk from the changes in the Southern Ocean were the generalist predator/scavengers Ophionotus victoriae and the starfish, Odontaster validus.

However, most species were predicted to have a negative response to at least one environmental factor. Only Odontaster validus, Parborlasia corrugatus and gelatinous zooplankton were predicted to have positive responses for every risk factor that could be scored.

\section{Marine Ectotherm Trophic Guilds}

All marine ectotherm trophic guilds were predicted to benefit, or not be affected, in the case of grazers, by the changes in the environment of the Southern Ocean (Table 4). Deposit feeders and scavengers were the functional groups expected to benefit most from the changes.

\section{Marine Endotherms}

Three marine endotherms were scored with positive summed responses and three with negative overall responses to climate change (Table 5). However, only Eubalaena australis and Aptenodytes patagonicus had summed positive or neutral responses for both direct and indirect risk factors, and only $E$. australis had no negative scores for any of the environmental factors. Most of the negative risk was realized through the food web as indirect risk factors.

\section{DISCUSSION}

\section{Ectotherms}

The ectotherms considered most at risk were species, such as the Liothyrella uva, the clam, Laternula elliptica and the amphipod, Paracerodocus miersi (Table 3). All three species are amongst the most temperature-sensitive, with both long term limits and burrowing limits of L. elliptica having an upper temperature of between 2 and $3^{\circ} \mathrm{C}$ (Peck et al., 2004) and both L. uva and $P$. merseii were unable to acclimate to $3^{\circ} \mathrm{C}$. Contrasting with this thermal sensitivity, L. elliptica has been found living in the intertidal zone at James Ross Island, where sediment temperatures were as high as $7^{\circ} \mathrm{C}$ (Waller et al., 2017). However, intertidal temperatures are only this high for a few hours, during low water in summer. L. elliptica exhibits acute capacity for physiological resistance, producing heat shock proteins at $6-8^{\circ} \mathrm{C}$ and are able to survive, in winter, for more than $36 \mathrm{~h}$ without breathing (Morley et al., 2007). The ability to survive short-term events, such as heat waves in summer and short-term intertidal exposure, is very different to vulnerability in the face of projected climate change. While limited warming has been observed in the shallow Western Antarctic Peninsula, all three of these animals have exoskeletons, and although studies to date have shown they are robust to reductions in seawater $\mathrm{pH}$ (Cross et al., 2015; Suckling et al., 2015; Morley et al., 2016), continued acidification is, however, predicted to increase the cost of making shells. Suspension feeders, such as L. elliptica and L. uva are expected to benefit from the break-up of ice shelves, increasing the area where spring phytoplankton blooms can occur (Peck et al., 2010a), increasing available habitats. The negative effect of reduced sea ice and ice shelf collapse is that iceberg scour will increase (Barnes, 2017b), increasing mortality in benthic communities in 
TABLE 3 | Risk assessment matrix for Polar marine invertebrate taxa.

\begin{tabular}{|c|c|c|c|c|c|c|c|c|}
\hline & Stress & OA & Sea ice & Temp & Ice scour & Ice shelf collapse & Sediment & Glacial retreat \\
\hline Expected direction & & + & - & + & + & + & + & + \\
\hline Species & Risk & & & & & & & \\
\hline Ophionotus victoriae (Brittlestar) & 6 & & 1 & -1 & 1 & 2 & 1 & 2 \\
\hline Odontaster validus (Starfish) & 5 & & 1 & 1 & 1 & 1 & & 1 \\
\hline Parborlasia corrugatus (Worm) & 5 & & 1 & & 2 & 1 & & 1 \\
\hline Molgula (Sea squirt) & 5 & & 1 & 1 & 1 & 1 & -1 & 2 \\
\hline Gelatinous zooplankton & 4 & 1 & 1 & & $\mathrm{~N} / \mathrm{A}$ & 1 & & 1 \\
\hline Aequiyoldia eightsi (Clam) & 4 & -1 & 1 & 1 & -1 & 1 & 1 & 2 \\
\hline Sponges & 3 & & 1 & 1 & -1 & 1 & -1 & 2 \\
\hline Spirorbid Polychaetes (Fan worms) & 3 & -1 & 1 & 1 & 1 & 1 & -1 & 1 \\
\hline Sterechinus neumayeri (Urchin) & 3 & & 0 & 1 & 1 & 1 & -1 & 1 \\
\hline Nacella concinna (Limpet) & 3 & & 1 & -1 & 1 & 1 & & 1 \\
\hline Fenestrulina rugula (Bryozoan) & 2 & -1 & 1 & 1 & 1 & 1 & -2 & 1 \\
\hline Glyptonotus antarctica (Sea slater) & 2 & & & -1 & 1 & 1 & & 1 \\
\hline Cnemidocarpa verrucosa (Sea squirt) & 2 & & & & 1 & 1 & -1 & 1 \\
\hline Paralomid decapods (Crabs/shrimps) & 2 & -1 & & 1 & 0 & 1 & & 1 \\
\hline Whip corals & 2 & -1 & 1 & 1 & -1 & 1 & & 1 \\
\hline Cellarinella nutti (Bryozoan) & 0 & -1 & 1 & 1 & -1 & & -1 & 1 \\
\hline Pycnogonida (Sea spiders) & 0 & & & -1 & & & & 1 \\
\hline Pteropods (Sea angels) & 0 & -1 & & & & & & 1 \\
\hline Beania erecta (Bryozoan) & 0 & & 0 & 1 & -2 & 1 & -1 & 1 \\
\hline Liothyrella uva (Lantern shell) & -1 & -1 & 1 & -1 & -1 & 1 & -1 & 1 \\
\hline Laternula elliptica (Clam) & -1 & -1 & 1 & -1 & -1 & & -1 & 2 \\
\hline Euphasia superba (Krill) & -2 & -1 & -1 & & & 1 & & \\
\hline Paracerodocus miersi (Amphipod) & -2 & -1 & & -1 & -1 & & & 1 \\
\hline
\end{tabular}

Colors from green to red are used to indicate increasing risk.

the upper $\sim 100 \mathrm{~m}$. Filter feeders are also, in general, expected to be negatively impacted by increased sedimentation from the increased melting of glaciers (Sahade et al., 2015). However, because of the impacts of sedimentation, ice scour and ocean acidification on benthic suspension and grazing species, these functional groups were predicted to be the ones to benefit least from the change in environmental factors (Table 4).

In general sediment dwellers, such as deposit feeders, e.g., Aequiyoldia eightsii, are likely to benefit (Tables 3, 4) because large areas of suitable soft sediment habitat are opening up on open shelf (from ice shelf break up) and along fjords (from glacial retreat). The ectotherm taxa that are predicted to benefit most from climate change, using our risk matrix, were suspension feeders, such as gelatinous zooplankton (salps and jellyfish), sponges and benthic predators and scavengers, such as Odontaster validus and Sterechinus neumayeri. The suspension feeders will benefit through the increased phytoplankton blooms, whereas the benthic predators will benefit from the mortality caused by increased ice berg scours. They are opportunistic predators who quickly move into recent ice berg scours to feed on dead and decaying organisms (Dunlop et al., 2014) and possibly surface microbial communities that will take advantage of the turned over nutrients. Smaller non-diatom phytoplankton may benefit as there is some evidence that they are increasing along parts of the WAP, coinciding with diatom decreases (Sailley et al., 2013). Other potential beneficiaries would include non-indigenous species invaders, with increased transport opportunities (more shipping and plastic) and less severe conditions enhancing establishment success-this would likely lead to strong negative impacts on surrounding native species.

\section{Marine Ectotherm Trophic Guilds}

The impacts of climate change are expected to have a greater effect on calcareous suspension feeders because of the impact of ocean acidification and the increased ice berg scour due to the loss of sea ice and ice shelves (Table 4). This negative impact is predicted to outweigh the positive effects of increased primary productivity in the shallows, but the reverse may be true in deeper water (which covers most of the shelf). The greater disturbance has already had a profound effect on shallow water Antarctic benthos (Barnes, 2017b). The community structure has been altered toward favoring pioneers, particularly a single bryozoan species, Fenestrula rugula (Barnes et al., 2014). The favoring of pioneer species was also found when the temperature of the colonizing substratum was raised by $1^{\circ} \mathrm{C}$ (Ashton et al., 2017), with the same pioneering bryozoan increasing its growth rate to dominate the available space. Within each of these guilds there 
TABLE 4 | Matrix summarizing the risk for different marine ectotherm functional groups.

\begin{tabular}{|c|c|c|c|c|c|c|c|c|c|}
\hline & Stress & OA & Sea ice & Temp & $\begin{array}{c}\text { Ice } \\
\text { scour }\end{array}$ & $\begin{array}{l}\text { Ice shelf } \\
\text { collapse }\end{array}$ & Sediment & Snowfall & $\begin{array}{l}\text { Glacial } \\
\text { retreat }\end{array}$ \\
\hline Expected direction & & + & - & + & + & + & + & + & + \\
\hline Species & Risk & & & & & & & & \\
\hline Deposit feeders & 5 & 0 & 1 & 1 & -1 & 1 & 1 & & 2 \\
\hline Scavengers & 4 & & 1 & 1 & 1 & 1 & & & 0 \\
\hline Predators & 3 & & 1 & & 1 & 1 & & & \\
\hline $\begin{array}{l}\text { Non-Calcareous } \\
\text { Benthic Suspension } \\
\text { Feeders }\end{array}$ & 2 & 0 & 1 & 1 & -1 & 1 & -1 & & 1 \\
\hline $\begin{array}{l}\text { Calcareous Benthic } \\
\text { Suspension Feeders }\end{array}$ & 1 & -1 & 1 & 1 & -1 & 1 & -1 & & 1 \\
\hline Grazers & 0 & -1 & 1 & 1 & -1 & 1 & -1 & & 0 \\
\hline
\end{tabular}

Colors from green to yellow are used to indicate increasing risk.

will clearly be winners and losers, with selection for species with rapid growth rates, early reproduction and rapid colonization. Longer phytoplankton blooms, with more smaller cells, are likely to benefit suspension and deposit feeders in deeper water as they will get longer meal times and more growth (Barnes, 2017a).

Deposit feeders are expected to benefit as they will receive more organic material from longer phytoplankton blooms, more habitat and the increased melt water from glaciers, which increases the input of glacial flour into bays and subsequent benthic sedimentation (Sahade et al., 2015). For example, in Potter Cove, King George/25 de Mayo Island in the South Shetland Islands, there has been a shift away from a filter feeder-dominated community to a more mixed community. This shift is thought to be due to the increased sedimentation clogging filter mechanisms benefitting species with alternate feeding modes (because of reduced competition for space and resources).

The increased mortality from increases in ice-berg scour is one of the key attributes that suggests scavengers and generalist predators are one of the trophic guilds that are predicted to benefit, at least in the medium term, from climate change. If, however, one of the key prey species (such as the limpet Nacella concinna) disappears from the shallows, then the success of these predators in the shallows will depend of the balance of prey availability and if a suitable prey species takes over. We do not have enough information to understand the indirect effects of climate change on marine ectotherms.

\section{Endotherms}

The most vulnerable endotherm to the direct effects of climate change in this study was the emperor penguin, A. forsteri (Table 5). It is vulnerable due to loss of its breeding habitat on sea ice and ice shelves. A. forsteri do not feed on krill and it is possible that the abundance of their fish prey will increase in open water, but this is currently unknown. All species that breed on land, or on ice, are expected to be affected by increased snowfall, linked to warming atmospheric temperatures (Thomas et al., 2017). Of course this will be countered by the increased number of melt days during summer (Barrand et al., 2013), however, it is the date at which the snow accumulation melts out on historical sites for penguin colonies that determines the time of the start of the breeding season (Trivelpiece and Fraser, 1966).

The endotherm that is predicted to gain most from the direct effects of climate change is the king penguin, Aptenodytes patagonicus. It is not a krill but a fish feeder and its main food, myctophids, are likely to benefit from reduced sea ice and collapses in ice shelves, which will lead to increased areas for primary productivity (Sailley et al., 2013). Increased knowledge of the strength of food web interactions will improve the layer of physiological vulnerability by adding the complexity of these interactions. A. patagonicus also nests on glacial plains in front of glaciers. As these glaciers recede, the area available for the breeding colony will increase, reducing competition for space within the breeding colony and ultimately improving breeding success.

The indirect effects of climate change, those that act through the food chain, have already been assessed through the marine ectotherms, where ice-associated food, such as E. superba, is expected to suffer. When these indirect effects are considered, the krill feeding sea ice-associated penguins, Pygoscelis adeliae and $P$. antarctica are assessed to be most at risk. This risk is, however, mitigated by the potential that the distribution of these penguins and their prey are migrating south, and their populations are in fact stable.

For cetaceans, the krill feeders are expected to do badly, e.g., the humpback whale, Megaptera novaeangliae, due to the reduction in krill populations. However, if, as for the penguins discussed above, krill populations have not reduced but simply tracked the southern trajectory of the ice, then this risk may be substantially reduced. For non-E. superba feeding cetaceans, such as the southern right whales Eubalanus australis, the prospects are favorable, as their main food-copepods-may be one of the species that benefits from the increase in open water and increased primary productivity. This may be one of the species that continues its current rate of recovery from the historical impacts of human exploitation (Jackson et al., 2016). 
TABLE 5 | Risk assessment matrix for marine endotherms.

\begin{tabular}{|c|c|c|c|c|c|c|c|c|c|}
\hline & & & Stress & OA & Sea ice & Temp & $\begin{array}{l}\text { Ice shelf } \\
\text { collapse }\end{array}$ & Snowfall & $\begin{array}{l}\text { Glacial } \\
\text { retreat }\end{array}$ \\
\hline & & & $\begin{array}{l}\text { Expected } \\
\text { direction }\end{array}$ & + & - & + & + & + & + \\
\hline Species & $\begin{array}{l}\text { Total } \\
\text { risk }\end{array}$ & & Risk & & & & & & \\
\hline \multirow[t]{2}{*}{ Eubalaena australis (Southern right whale) } & 4 & Direct & 1 & & & 1 & & & \\
\hline & & Indirect & 3 & & 1 & 1 & 1 & & \\
\hline \multirow[t]{2}{*}{ Aptenodytes patagonicus (King penguin) } & 3 & Direct & 3 & & 1 & 1 & 1 & -1 & 1 \\
\hline & & Indirect & 0 & & & & & & \\
\hline \multirow[t]{2}{*}{ Megaptera novaeangliae (Humpback whale) } & 1 & Direct & 4 & & 1 & 1 & 1 & & 1 \\
\hline & & Indirect & -3 & -1 & -1 & -1 & & & \\
\hline \multirow[t]{2}{*}{ Arctocephalus gazelle (Fur seal) } & 0 & Direct & 1 & & & 1 & 1 & -1 & \\
\hline & & Indirect & -1 & -1 & -1 & -1 & & & \\
\hline \multirow[t]{2}{*}{ Orcinus orca (Pack ice killer whale) } & 0 & Direct & 2 & & -1 & 1 & 1 & & 1 \\
\hline & & Indirect & -2 & -1 & -1 & -1 & & & 1 \\
\hline \multirow[t]{2}{*}{ Aptenodytes forsteri (Emperor penguin) } & -2 & Direct & -2 & & -1 & 1 & -1 & -1 & \\
\hline & & Indirect & 0 & & & & & & \\
\hline \multirow[t]{2}{*}{ Pygoscelis adeliae (Adèlie penguin) } & -4 & Direct & -1 & & -1 & 1 & & -1 & \\
\hline & & Indirect & -3 & -1 & -1 & -1 & & & \\
\hline \multirow[t]{2}{*}{ Pygoscelis Antarctica (Chinstrap penguin) } & -4 & Direct & -1 & & -1 & 1 & & -1 & \\
\hline & & Indirect & -3 & -1 & -1 & -1 & & & \\
\hline
\end{tabular}

Both direct and indirect (through the food web) effects are reported and summed. Colors from green to red are used to indicate increasing risk.

\section{Species Range Shifts and Invasions}

Most Antarctic marine ectotherms have nowhere colder to migrate to Peck (2005). There may be some additional open water habitats created when ice shelves collapse, and the break-up of the Ross ice shelf (if it happens) would create the furthest south open water, but the geographic migration potential is extremely low. For example, there is evidence that most benthic ectotherms on South Georgia's outermost shelf have made little progress reinvading the inner shelf after the Last Glacial Maximum more than 20 kya (Barnes et al., 2016). An analysis of species range limits within the Southern Ocean suggested that this location, South Georgia, was amongst the most likely places to detect climate-forced range shifts (Barnes et al., 2009). A recent study based on climate envelope models predicted a 79\% reduction in suitable temperature habitat under predicted climate change (Griffiths et al., 2017). When a layer of physiological tolerance is overlain on this projected climate envelope, this potential reduction is expected to be more severe. However, there is an argument that East Antarctica is one of the least changing environments and, in combination with eurybathy, species on the majority of the Antarctic shelf have the least need to migrate (Barnes and Peck, 2008).

The Southern Ocean is bordered by the major southern hemisphere continents South America, Africa and the Australasia. The Antarctic circumpolar current and the sharp temperature gradient across the polar front currently act as a rarely permeable barrier to a range of cold temperate fauna that are living at the northern edge of the Southern
Ocean (Clarke et al., 2005). These will have increased potential to migrate south and colonize the Southern Ocean as it continues to warm. There are currently no marine invasive species in the Southern Ocean, but species, such as the Patagonian gastropods Nacella magellanica and Siphonaria spp. will have increased chances to make it across the Drake Passage and particularly to the northern Antarctic Peninsula and the northern islands. Species that can raft across the polar front by hitching a ride on floating seaweed, megafauna, plastic or ships are likely to be the first invasives (Lewis et al., 2006; González-Wevar et al., 2018).

\section{Human Impacts}

Human society is geographically distant, so anthropogenic associations are limited to a few introduced terrestrial species and the impacts of harvesting. The current impacts of human activity are, however, global and are encroaching into Antarctica (Gutt et al., 2015). The number of tourist and scientific vessels is ever increasing, as is the level of plastic in the ocean (Barnes et al., 2018). These increase the number of available vectors for invasive species to reach the Antarctic (Lee and Chown, 2007). Currently, all fisheries within polar waters around Antarcticaincluding the harvesting of Antarctic krill (Euphausia superba) take place under the management of the Commission for the Conservation of Antarctic Marine Living resources (CCAMLR). Central to the management policies of CCAMLR is the ecosystem approach it employs to determine the setting of catch limits. This entails utilizing scientific data collected from a range of marine 
higher predators including seabirds, penguins, seals and whale species to ensure that management of its various fisheries takes into account the requirements of such krill-dependent predators. Nevertheless, as noted by Trathan et al. (2015), the advent of more efficient krill extraction technology, together with the opening up of new consumer markets for what is currently one of the last remaining large exploitable sources of marine protein, would all indicate a likely future expansion of this fishery. Unless carefully controlled, impacts on predator species including penguins and seals could be significant (Warwick-Evans et al., 2018). For example, limited availability of Antarctic krill around South Georgia, in this case driven by increasing environmental variability, is already negatively impacting breeding Antarctic fur seals through loss of life history buffering (Forcada et al., 2008). Further reductions in krill availability caused by increased catch limits for fisheries would be likely to compound this process, adding to the fitness costs of fur seals and in particular breeding females.

\section{Incorporating Greater Complexity Into Ecological Risk Assessment}

From the available literature the responses of Antarctic marine fauna allowed a semi-quantitative risk assessment of the impact of climate change. These assessments will clearly be improved as more data are published. Our risk assessment only scored a positive or negative response to each factor. The assumption that each factor should be equally weighted is unlikely to be realistic and, as has already been discussed, the effect of some factors, such as temperature, are thought to be more important to Antarctic marine ectotherms than other factors, such as ocean acidification.

It is also important to integrate knowledge of interactions through the food web, increasing the accuracy with which marine ectotherms can be risk assessed. The inclusion of indirect factors into the risk assessment for endotherms is the first stage in building more comprehensive risk assessments. For example, temperature and other environmental factors are known to influence the nutritional quality of prey as well as the nutritional requirements of predators. Incorporating nutritional ecology into assessments of climate change effects (Rosenblatt and Schmitz, 2016; Machovsky-Capuska et al., 2018) is just one of the improvements that will become possible as data availability increases. Our knowledge of the importance of factors that are likely to mitigate or even feedback against climate change, can be incorporated in more complex assessments.

\section{Mitigating Factors}

The major mitigation against climate change is carbon sequestration. Most carbon that is genuinely sequestered (i.e., buried and ultimately converted into rock) happens at the seabed. Although many low-latitude habitats, such as forests, kelp forests, seagrass beds and mangrove swamps (amongst others) are efficient at carbon capture and storage, they may provide poor negative feedbacks (on climate). This is because they are all decreasing as sinks (because of area loss) and not much of the carbon is buried. Benthos on polar and subpolar shelves in contrast are minor sinks in terms of carbon capture and storage values, but substantial in terms of sequestration and as a negative feedback mechanism (Barnes et al., 2018). This is because they store carbon at the seabed interface (i.e., site of burial) and are increasing their growth and carbon storage as a result of reductions in sea-ice, leading to longer phytoplankton blooms (Barnes, 2015); increasing habitat due to both glacial retreat (Cook et al., 2005) and ice shelf collapse (Peck et al., 2010a); as well as giant iceberg activity (Duprat et al., 2016; Barnes et al., 2018).

Along with many Antarctic marine ectotherms, Antarctic demosponges were thought to live life in the slow lane (Dayton et al., 1974). However, recently sponges have been found to respond rapidly to the opening up of new areas of the ocean (Fillinger et al., 2013) that now receive enough light for primary productivity to occur in summer, after events, such as ice shelf collapse (Peck et al., 2010a). Whilst the greater-thanexpected plasticity of sponges may be linked to their symbiotic communities (Morley et al., 2016), other taxa, such as ascidians and bryozoans have also been found to grow and colonize rapidly under these altered conditions (Barnes et al., 2011).

Whilst many studies have investigated the effects of climate stressors on either adults or during fertilization and development, few studies have utilized long term incubations to investigate the effect of acclimation in adults, or during development. Recent experiments using Antarctic marine ectotherms have found that acclimation capacity is poor, but if adults are able to adjust their physiology, it can take 5-9 months for acclimation to occur (Peck et al., 2010b, 2014). After these long-term incubations, some Antarctic ectotherms exhibit unexpectedly high acclimation capacities (Morley et al., in press). Also, one of the few studies to incubate adults long term (18 months), through the majority of gonad development, found that after 8 months, adult Sterechinus neumayeri were fully acclimated to a combination of $\mathrm{OA}$ and elevated temperature treatments (Suckling et al., 2015). This study also found that the hatching and larval survival of adults spawned after 17 months of exposure to altered conditions was not significantly affected by these treatment combinations (Suckling et al., 2015).

The impact of altered conditions during adult and embryo development can lead to cross-generation changes in physiological plasticity (Donelson et al., 2011; Salinas et al., 2013). These changes can be fixed in future generations, socalled epigenetic effects, even if environmental stressors are removed (Klironomos et al., 2013). Also, there is the possibility for selection to occur rapidly, with larvae with more tolerant phenotypes surviving through to the next generation, all of which can lead to rapid evolution, even in long-lived species (Thompson, 1998). The projected warming combined with the stenotypic nature of the fauna suggests that population genetic studies within the Southern Ocean may yield the best evidence of selection for more tolerant phenotypes. Due to the extended time to reach maturity for some Antarctic marine ectotherms (Peck, 2011) we are not aware of any multi-generational studies that have been conducted in the Antarctic. If such rapid evolutionary change can occur in the Antarctic, then it has the potential to mitigate many of the impacts predicted due to climate change (Zizzari and Ellers, 2014; Donelson and Munday, 2015). 
The earth is currently in an interglacial period, with warming temperatures, but the shelf seas around the Antarctic have been almost completely covered by ice during recent glacial maxima (Clarke and Crame, 1989). The requirement to migrate on and off the shelf is thought to have been driven by glacial-interglacial cycles, resulting in many of the surviving Antarctic shelf species having eurybathic distributions (Brey et al., 1996). Eurybathy may not only have allowed species a refuge from glaciation but may now also provide a refuge from many of the impacts of climate change (which are mainly occurring toward the surface waters).

In contrast to the dramatic message of more losers than winners gained from single factor studies, when multiple factors are considered the resilience of many Antarctic marine species is highlighted. However, while the understanding of the relative effects of different stressors is improving, more information is required to improve the accuracy of such risk assessments. This will be further improved when the

\section{REFERENCES}

Aronson, R. B., Frederich, M., Price, R., and Thatje, S. (2015). Prospects for the return of shell-crushing crabs to Antarctica. J. Biogeogr. 42, 1-7. doi: $10.1111 /$ jbi.12414

Arrigo, K. R., van Dijken, G. L., and Bushinsky, S. (2008). Primary production in the Southern Ocean, 1997-2006. J. Geophys. Res. 113:C08004. doi: 10.1029/2007JC004551

Ashton, G. V., Morley, S. A., Barnes, D. K. A., Clark, M. S., and Peck, L. S. (2017). Warming by $1{ }^{\circ} \mathrm{C}$ drives species and assemblage level responses in Antarctica's Marine Shallows. Curr. Biol. 27, 2698-2705. doi: 10.1016/j.cub.2017.07.048

Atkinson, A., Siegel, V., Pakhomov, E., and Rothery, P. (2004). Long-term decline in krill stock and increase in salps within the Southern Ocean. Nature 432, 100-103. doi: 10.1038/nature02996

Barnes, D. K. A. (1995). Seasonal and annual growth in erect species of Antarctic bryozoans. J. Exp. Mar. Biol. Ecol. 188, 181-198. doi: 10.1016/0022-0981(95)00003-A

Barnes, D. K. A. (2015). Antarctic sea ice losses drive gains in benthic carbon drawdown. Curr. Biol. 25, 789-790. doi: 10.1016/j.cub.2015.07.042

Barnes, D. K. A. (2017a). Polar zoobenthos blue carbon storage increases with sea ice losses, because across-shelf growth gains from longer algal blooms outweigh ice scour mortality in the shallows. Glob. Chang Biol. 23, 5083-5091. doi: $10.1111 /$ gcb.13772

Barnes, D. K. A. (2017b). Iceberg killing fields limit huge potential for benthic blue carbon in Antarctic shallows. Glob. Change Biol. 23, 2649-2659. doi: $10.1111 /$ gcb.13523

Barnes, D. K. A., Fenton, M., and Cordingley, A. (2014). Climate-linked iceberg activity massively reduces spatial competition in Antarctic shallow waters. Curr. Biol. 24:R2. doi: 10.1016/j.cub.2014.04.040

Barnes, D. K. A., Griffiths, H. J., and Kaiser, S. (2009). Geographic range shift responses to climate change by Antarctic benthos: where we should look. Mar. Ecol. Prog. Ser. 393, 13-26. doi: 10.3354/meps08246

Barnes, D. K. A., Ireland, L., Hogg, O. T., Morley, S. A., Enderlein, P., and Sands, C. J. (2016). Why is the South Orkney Island shelf (the world's first high seas marine protected area). a carbon immobilization hotspot? Glob. Change Biol. 22, 1110-1120. doi: $10.1111 /$ gcb. 13157

Barnes, D. K. A., and Kuklinski, P. (2010). Bryozoans of the Weddell Sea continental shelf, slope and abyss: Did marine life colonize the Antarctic shelf from deep water, outlying islands or in situ refugia following glaciations? J. Biogeog. 37, 1648-1656. doi: 10.1111/j.1365-2699.2010.02320.x

Barnes, D. K. A., Kuklinski, P., Jackson, J. A., Keel, G. W., Morley, S. A., and Winston, J. E. (2011). Scott's collections help reveal accelerating marine life growth in Antarctica. Curr. Biol. 22:R148. doi: 10.1016/j.cub.2011.01.033 vulnerability of links within the food web can be described in detail, allowing the true vulnerability of Antarctic marine fauna to be more completely assessed. These principles are not unique to the Antarctic and the principles outlined above can be applied across latitudes and systems where data is limited.

\section{AUTHOR CONTRIBUTIONS}

All authors listed have made a substantial, direct and intellectual contribution to the work, and approved it for publication.

\section{ACKNOWLEDGMENTS}

All authors were supported through core funding from the Natural Environment Research Council to the British Antarctic Survey's "Biodiversity Adaptation and Evolution" and "Ecosystem" Teams.
Barnes, D. K. A., Morley, S. A., Bell, J., Brewin, P., Brigden, K., Collins, M., et al. (2018). Marine plastics threaten giant Antarctic marine protected areas. Curr. Biol. 28, 1121-1142. doi: 10.1016/j.cub.2018.08.064

Barnes, D. K. A., and Peck, L. S. (2008). Vulnerability of Antarctic shelf biodiversity to predicated regional warming. Clim. Res. 37, 149-163. doi: 10.3354/cr00760

Barnes, D. K. A., and Souster, T. (2011). Reduced survival of Antarctic benthos linked to climate-induced iceberg scour. Nat. Clim. Change 1, 365-368. doi: $10.1038 /$ nclimate 1232

Barrand, N. E., Vaughan, D. G., Steiner, N., Tedesco, M., Kuipers Munneke, P., ven den Broeke, M. R., et al. (2013). Trends in Antarctic Peninsula surface melting conditions from observations and regional climate modelling. J. Geophys. Res. 118, 315-330. doi: 10.1029/2012JF002559

Bednaršek, N., Tarling, G. A., Bakker, D. C. E., Fielding, S., Cohen, A., Kuzirian, A., et al. (2012). Description and quantification of pteropod shell dissolution: a sensitive bioindicator of ocean acidification. Glob. Change Biol. 18, 2378-2388. doi: 10.1111/j.1365-2486.2012.02668.x

Bjork, M. M., Fransson, A., Torstensson, A., and Chierici, M. (2014). Ocean Acidification State in Western Antarctic surface waters: controls and interannual variability. Biogeosciences 11, 57-73. doi: 10.5194/bg-11-57-2014

Bray, L., Pancucci-Papadopulou, M. A., and Hall-Spencer, J. M. (2014). Sea urchin response to rising $\mathrm{pCO}_{2}$ shows ocean acidification may fundentally alter the chemistry of marine skeletons. Medit. Mar. Sci. 15, 510-519. doi: $10.12681 / \mathrm{mms} .579$

Brey, T., Dahm, C., Gorny, M., Klages, M., Stiller, M., and Arntz, W. E. (1996). Do Antarctic benthic invertebrates show an extended level of eurybathy? Ant. Sci. 8, 3-6. doi: 10.1017/S0954102096000028

Brierley, A. S., Fernandes, P. G., Brandon, M. A., Armstrong, F., Millard, N. W., McPhail, S. D., et al. (2002). Antarctic krill under sea ice: elevated abundance in a narrow band just south of ice edge. Science 295, 1890-1892. doi: $10.1126 /$ science.1068574

Chapelle, G., and Peck, L. S. (1996). Polar gigantism dictated by oxygen availability. Nature 399, 114-115. doi: 10.1038/20099

Clarke, A. (1988). Seasonality in the Antarctic marine ecosystem. Compar. Biochem. Physiol. 90, 461-473.

Clarke, A., Barnes, D. K. A., and Hodgson, D. A. (2005). How isolated is Antarctica? Trends Ecol. Evol. 20, 1-3. doi: 10.1016/j.tree.2004.10.004

Clarke, A., and Crame, J. A. (1989). "The origin of the Southern Ocean Marine Fauna," in Origins and Evolution of the Antarctic Biota, ed J. A. Crame (London: Geological Society Special Publication), 253-268. doi: 10.1144/GSL.SP.1989.047.01.19

Clarke, C., and Crame, J. A. (1992). The Southern Ocean fauna and climate change: a historical perspective [and discussion]. Phil. Trans. Soc. Lond. B 338,299-309. doi: $10.1098 /$ rstb.1992.0150 
Collar, N. J., Crosby, M. J., and Stattersfield, A. J. (1994). Birds to Watch 2: The World List of Threatened Birds. BirdLife Conservation series No. 4. Cambridge: BirdLife International.

Collard, M., De Ridder, C., David, B., Dehairs, F., and Dubois, P. (2015). Could the acid-base status of antarctic sea urchins indicate a better-than-expected resilience to near-future ocean acidification? Glob. Change Biol. 21, 605-617. doi: $10.1111 /$ gcb. 12735

Cook, A. J., Fox, A. J., Vaughan, D. G., and Ferrigno, J. G. (2005). Retreating glacier fronts on the Antarctic Peninsula over the last half-century. Science 308, 541-544. doi: 10.1126/science.1104235

Cook, A. J., Holland, P. R., Meredith, M. P., Murray, T., Luckman, A., and Vaughan, D. G. (2016). Ocean forcing of glacier retreat in the Western Antarctic Peninsula. Science 353, 283-286. doi: 10.1126/science.aae0017

Cross, E. L., Peck, L. S., and Harper, E. M. (2015). Ocean acidification does not impact shell growth or repair of the Antarctic brachiopod Liothyrella uva (Broderip, 1833). J. Exp. Mar. Biol. Ecol. 462, 29-35. doi: 10.1016/j.jembe.2014.10.013

Croxall, J. P., Trathan, P. N., and Murphy, E. J. (2002). Environmental change and Antarctic seabird populations. Science 297, 1510-1514. doi: $10.1126 /$ science. 1071987

Dayton, P. K., Robilliard, G. A., Paine, R. T., and Dayton, L. B. (1974). Biological accommodation in the benthic community at McMurdo sound, Antarctica. Ecol. Monogr. 44, 105-128. doi: 10.2307/1942321

De Broyer, C., Koubbi, P., Griffiths, H. J., Raymond, B., Udekem d'Acoz, C. d', Van de Putte, A. P., et al. (Eds.). (2014). Biogeographic Atlas of the Southern Ocean. Cambridge: Scientific Committee on Antarctic Research, XII + 498pp.

DeVries, A. L. (1971). Glycoproteins as biological antifreeze agents in Antarctic fishes. Science 172, 1152-1155. doi: 10.1126/science.172.3988.1152

Donelson, J. M., Munday, P., and McCormick, M. I. (2011). Acclimation to predicted ocean warming through developmental plasticity in a tropical reef fish. Glob. Change Biol. 17, 1712-1719. doi: 10.1111/j.1365-2486.2010.02339.x

Donelson, J. M., and Munday, P. L. (2015). Transgenerational plasticity mitigates the global warming to offspring sex ratios. Glob. Change Biol. 21, 2954-2962. doi: $10.1111 /$ gcb.12912

Dunlop, K. M., Barnes, D. K. A., and Bailey, D. M. (2014). Variation of scavenger richness and abundance between sites of high and low iceberg scour frequency in Ryder Bay, west Antarctic Peninsula. Polar Biol. 12, 1741-1754. doi: 10.1007/s00300-014-1558-y

Dunn, M. J., Jackson, J. A., Adlard, S., Lynnes, A. S., Briggs, R. B., Fox, D., et al. (2016). Population size and decadal trends of three penguin species nesting at Signy Island, South Orkney Islands. PLoS ONE 11:e0164025. doi: 10.1371/journal.pone.0164025

Duprat, L. P. A. M., Bigg, G. R., and Wilton, D. J. (2016). Enhanced Southern Ocean marine productivity due to fertilization by giant icebergs. Nat. Geosci. 9, 219-221. doi: 10.1038/ngeo2633

Fillinger, L., Janussen, D., Lundălv, T., and Richter, C. (2013). Rapid glass sponge expansion after climate-induced Antarctic shelf collapse. Curr. Biol. 23, 1330-1334. doi: 10.1016/j.cub.2013.05.051

Forcada, J., Trathan, P. N., and Murphy, E. J. (2008). Life history buffering in Antarctic mammals and birds against changing patterns of climate and environmental variation. Glob. Chang. Biol. 14, 2473-2488. doi: 10.1111/j.1365-2486.2008.01678.x

Forcada, J., Trathan, P. N., Reid, K., and Murphy, E. J. (2005). The effects of global climate variability in pup production of Antarctic fur seals. Ecology 86, 2408-2417. doi: 10.1890/04-1153

González-Wevar, C. A., Segovia, N. I., Rosenfeld, S., Ojeda, J., Hüne, M., Naretto, J., et al. (2018). Unexpected absence of island endemics: long-distance dispersal in higher latitude sub-Antarctic Siphonaria (Gastropoda: Euthyneura) species. J. Biogeogr. 45, 847-884. doi: 10.1111/jbi.13174

Griffiths, H. J., Meijers, A. J. S., and Bracegirdle, T. J. (2017). More losers than winners in a century of Southern Ocean seafloor warming. Nat. Clim. Change 7, 749-754. doi: 10.1038/nclimate3377

Griffiths, H. J., Whittle, R. J., Roberts, S. J., Belchier, M., and Linse, K. (2013). Antarctic crabs: invasion or endurance? PLoS ONE 8:e66981. doi: 10.1371/journal.pone.0066981

Guinotte, J. M., and Fabry, V. J. (2008). Ocean acidification and its potential effects on marine ecosystems. Ann. N. Y. Acad. Sci. 1134, 320-342. doi: $10.1196 /$ annals. 1439.013
Gutt, J., Bertler, N., Bracegirdle, T. J., Buschmann, A., Comiso, J., Hosie, G., et al. (2015). The Southern Ocean system under multiple climate change stresses - an integrated circumpolar assessment. Glob. Change Biol. 21, 1434-1453. doi: $10.1111 / \mathrm{gcb} .12794$

Hain, S., and Arnaud, P. M. (1992). "Notes on the reproduction of high Antarctic molluscs from the Weddell Sea," in Weddell Sea Ecology. Results of EPOS European Polarstern Study, ed G. Hempel (Berlin: Springer). Polar Biol. 12, 303-312. doi: 10.1007/978-3-642-77595-6

Hinke, J. T., Salwicka, K., Trivelpiece, S. G., Watters, G. M., and Trivelpiece, W. Z. (2007). Divergent responses of Pygoscelis penguins reveal a common environmental driver Oecologia 153, 845-855. doi: 10.1007/s00442-007-0781-4

Holland, P. R., and Kwok, R. (2012). Wind-driven trends in Antarctic sea-ice drift. Nat. Geosci. 5, 872-875. doi: 10.1038/ngeo1627

Holsman, K., Samhouri, J., Cook, G., Hazen, E., Olsen, E., Dillard, M., et al. (2017). An ecosystem-based approach to marine risk assessment, ecosystem health and sustainability. Ecosyst. Health Sustain. 3:e10256IPCC. doi: 10.1002/ehs2.1256

IPCC (2013). Climate Change 2013: The Physical Science Basis. Contribution of Working Group I to the Fifth Assessment Report of the Intergovernmental Panel on Climate Change, eds T. F. Stocker, D. Qin, G. -K. Plattner, M. Tignor, S. K. Allen, J. Boschung, A. Nauels, Y. Xia, V. Bex, and P. M. Midgley (Cambridge, UK; New York, NY: Cambridge University Press), 1535. doi: $10.1017 / \mathrm{CBO} 9781107415324$

Jackson, J. A., Carroll, E. L., Smith, T. D., Zerbini, A. N., Patenaude, N. J., and Baker, C. S. (2016). An integrated approach to historical population assessment of the great whales: case of the New Zealand southern right whale. R. Soc. Open Sci. 3:150669. doi: 10.1098/rsos.150669

Jacobs, S. S., Giulivi, C. F., and Mele, P. A. (2002). Freshening of the Ross Sea during the late 20th Century. Science 297, 386-389. doi: 10.1126/science.1069574

Karentz, D., and Bosch, I. (2001). Inluence of ozone-related increases in ultraviolet radiation on Antarctic marine organisms. Am. Zool. 41, 3-16. doi: $10.1093 / \mathrm{icb} / 41.1 .3$

Karr, J. R., and Chu, E. W. (1997). Biological monitoring: essential foundation for ecological risk assessment. Hum. Ecol. Risk Assess. 3, 993-1004. doi: $10.1080 / 10807039709383742$

Kennicutt, M. C., Chown, S. L., Cassano, J. J., Liggett, D., Massom, R., Peck, L. S., et al. (2014). Polar research: six priorities for Antarctic science. Nature 512, 23-25. doi: 10.1038/512023a

Klironomos, F. D., Berg, J., and Collins, S. (2013). How epigenetic mutations can affect evolution: model and mechanism. Bioessays 35, 571-578. doi: 10.1002/bies.201200169

Lee, J. E., and Chown, S. L. (2007). Mytilus on the move: transport of an invasive bivalve to the Antarctic. Mar. Ecol. Prog. Ser. 339, 307-310. doi: 10.3354/meps339307

Lewis, P. N., Bergstrom, D. M., and Whinam, J. (2006). Barging in: a temperate marine community travels to the Subantarctic. Biol. Invasions 8, 787-795. doi: 10.1007/s10530-005-3837-6

Lynch, H. J., Naveen, R., and Fagan, W. F. (2012). Spatially integrated assessment reveals widespread changes in penguin populations on the Antarctic Peninsula. Ecology 93, 1367-1377. doi: 10.1890/11-1588.1

Machovsky-Capuska, G. E., Miller, M. G. R., Silva, F. R. O., Amiot, C., Stockin, K. A., Senior, A. M., et al. (2018). The nutritional nexus: linking habitat variability and prey composition in a generalist marine predator. J. Animal Ecol. 87, 1286-1298. doi: 10.1111/1365-2656.12856

McKinney, M. L., and Lockwood, J. L. (1999). Biotic homogenization: a few winners replacing many losers in the next mass extinction. Trends Ecol. Evol. 14, 450-453. doi: 10.1016/S0169-5347(99)01679-1

Meredith, M. P., and King, J. C. (2005). Rapid climate change in the ocean west of Antarctic Peninsual during the second half of the 20th century. Geophys. Res. Let. 32:L19604. doi: 10.1029/2005GL024042

Miller, D. G. M. (1991). Exploitation of Antarctic marine living resources: a brief history and a possible approach to managing the krill fishery. S. African J. Mar. Sci. 10, 321-339. doi: 10.2989/02577619109504642

Morley, S. A., Martin, S. M., Day, R. W., Ericson, J., Lai, C.-H., and Lamare, M. (2012). Thermal reaction norms and the scale of temperature variation: latitudinal vulnerability of intertidal Nacellid limpets to climate change. PLoS ONE 7:e52818. doi: 10.1371/journal.pone.0052818

Morley, S. A., Peck, L. S., Miller, A. J., and Pörtner, H. O. (2007). Hypoxia tolerance associated with activity reduction is a key adaptation for Laternula 
elliptica seasonal energetics. Oecologia 153, 29-36. doi: 10.1007/s00442-0070720-4

Morley, S. A., Peck, L. S., Sunday, J., Heiser, S., and Bates, A. E. (in press). Physiological acclimation and persistence of ectothermic species under extreme heat events. Glob. Ecol. Biogeogr.

Morley, S. A., Suckling, C. S., Clark, M. S., Cross, E. L., and Peck, L. S. (2016). Long term effects of altered $\mathrm{pH}$ and temperature on the feeding energetics of the Antarctic sea urchin, Sterechinus neumayeri. Biodiversity 17:34-45 doi: 10.1080/14888386.2016.1174956

Murphy, E. J., Trathan, P. N., Watkins, J. L., Reid, K., Meredith, M. P., and Rothery, P. (2007). Climatically driven fluctuations in Southern Ocean ecosystems. Phil. Trans. R. Soc. Lond. B. Biol. Sci. 274, 3057-3067. doi: 10.1098/rspb.2007.1180

Orr, J. C., Fabry, V. J., Aumont, O., Bopp, L., Doney, S. C., Feely, R. A., et al. (2005). Anthropgenic ocean acidification over the twenty-first century and its impact on calcifying organisms. Nature 437, 681-686. doi: 10.1038/nature04095

Pearse, J. S., McClintock, J. B., and Bosch, I. (1991). Reproduction of Antarctic benthic marine invertebrates: tempos, modes and timing. Am. Zool. 31, 65-80. doi: $10.1093 / \mathrm{icb} / 31.1 .65$

Peck, L. S. (2005). Prospects for survival in the Southern Ocean: vulnerability of benthic species to temperature change. Ant. Sci. 17, 497-507. doi: 10.1017/S0954102005002920

Peck, L. S. (2011). Organisms and responses to environmental change. Mar. Genomics 4, 237-243. doi: 10.1016/j.margen.2011.07.001

Peck, L. S., Barnes, D. K. A., Cook, A. J., Fleming, A. H., and Clarke, A. (2010a). Negative feedback in the cold: ice retreat produces new carbon sinks. Glob. Change Biol. 16, 2614-2623. doi: 10.1111/j.1365-2486.2009.02071.x

Peck, L. S., Brockington, S., and Brey, T. (1997). Growth and metabolism in the Antarctic brachiopod Liothyrella uva. Phil. Trans. R. Soc. B. 352, 851-858. doi: 10.1098/rstb.1997.0065

Peck, L. S., Morley, S. A., and Clark, M. S. (2010b). Poor acclimation capacities in Antarctic marine ectotherms. Mar. Biol. 157, 2051-2059. doi: 10.1007/s00227-010-1473-x

Peck, L. S., Morley, S. A., Richard, J., and Clark, M. S. (2014). Acclimation and thermal tolerance in Antarctic marine ectotherms. J. Exp. Biol. 217, 16-22. doi: $10.1242 /$ jeb.089946

Peck, L. S., Webb, K. E., and Bailey, D. M. (2004). Extreme sensitivity of biological function to temperature in Antarctic marine species. Func. Ecol. 18, 625-630. doi: 10.1111/j.0269-8463.2004.00903.x

Pennisi, E. (2005). What determines species diversity. Science 309:90. doi: 10.1126/science.309.5731.90

Philipp, E. E. R., Husmann, G., and Abele D. (2011). The impact of sediment deposition and iceberg scour on the Antarctic soft shell clam, Laternula elliptica at King George Island, Antarctica. Ant. Sci. 23, 127-138. doi: 10.1017/S0954102010000970

Pörtner, H. O. (2002). Climate variations and the physiological basis of temperature dependent biogeography: systemic to molecular hierarchy of thermal tolerance in animals. Comp. Biochem. Physiol. A 132, 739-761. doi: 10.1016/S1095-6433(02)00045-4

Quentin, L. B., and Ross, R. M. (2001). Environmental variability and its impact on the reproductive cycle of Antarctic krill. Am. Zool. 41, 74-89. doi: $10.1093 /$ icb/41.1.74

Quentin, L. B., and Ross, R. M. (2003). Episodic recruitment in Antarctic krill Euphausia superba in the palmer LTER study region. Mar. Ecol. Prog. Ser. 259, 185-200. doi: 10.3354/meps259185

Rosenblatt, A. E., and Schmitz, O. J. (2016). Climate change, nutrition and bottom-up and top-down food web processes. Trends Ecol. Evol. 31, 965-975. doi: $10.1016 /$ j.tree.2016.09.009

Ruud, J. T. (1954). Vertebrate without erythrocytes and blood pigment. Nature 173, 848-850. doi: 10.1038/173848a0

Sabine, C., Feely, R., Gruber, N., Key, R., Lee, K., Bullister, J., et al. (2004). The ocean sink for anthropogenic $\mathrm{CO}_{2}$. Science 305, 367-371. doi: 10.1126/science.1097403

Sahade, R., Lagger, C., Torre, L., Momo, P., Monien, P., Schloss, I., et al. (2015). Climate change and glacier retreat drive shifts in an Antarctic benthic ecosystem. Sci. Adv. 1:e1500050. doi: 10.1126/sciadv.1500050

Sailley, S., Ducklow, H. W., Moeller, H. V., Fraser, W. R., Schofield, O., Steinberg, D. K., et al. (2013). Carbon fluxes and pelagic ecosystem dynamics near two western Antarctic Peninsula Adelie penguin colonies: an inverse model approach. Mar. Ecol. Prog. Ser. 492, 253-272. doi: 10.3354/meps10534

Salinas, S., Mangel, M., Brown, S. C., and Munch, S. B. (2013). Non-genetic inheritance and changing environments. Non Genet. Inherit. 1, 38-50. doi: 10.2478/ngi-2013-0005

Smith, D. (2016). Has global warming stalled? Nat. Clim. Change 3, 618-619. doi: $10.1038 /$ nclimate 1938

Solomon, S. (1990). Progress towards a quantitative understanding of Antarctic ozone depletion. Nature 347, 347-354. doi: 10.1038/347347a0

Suckling, C. C., Clark, M. S., Richard, J., Morley, S. A., Thorne, M. A. S., Harper, E. M., et al. (2015). Adult acclimation to combined temperature and $\mathrm{pH}$ stressors significantly enhances reproductive outcomes compared to short-term exposures. J. Anim. Ecol. 84, 773-784. doi: 10.1111/1365-2656.12316

Takahashi, T., Sutherland, S. C., Wanninkhof, R., Sweeney, C., Feely, R. A., Chipman, D. W., et al. (2009). Climatological mean and decadal change in surface ocean $\mathrm{pCO}_{2}$, and net sea-air $\mathrm{CO}_{2}$ flux over the global oceans. Deep Sea Res. II, 56, 554-577. doi: 10.1016/j.dsr2.2008.12.009

Thomas, E. R., Melchior van Wessem, J., Roberts, J. Isaksson, E., Schlosser, E., Fudge, T. J., et al. (2017). Regional Antarctic snow accumulation over the past 1000 years. Clim. Past 13, 1491-1513. doi: 10.5194/cp-13-1491-2017

Thompson, D. W. J., Solomon, S., Kushner, P. J., England, M. H., Grise, K. M., and Karoly, D. J. (2011). Signatures of the Antarctic ozone hole in southern hemisphere surface climate change. Nat. Geosci. 4, 741-749. doi: 10.1038/ngeo1296

Thompson, J. N. (1998). Rapid evolution as an ecological process. Trends Ecol. Evol. 13, 329-332. doi: 10.1016/S0169-5347(98)01378-0

Trathan, P. N., Forcada, J., and Murphy, E. J. (2007). Environmental forcing and Southern Ocean marine predator populations: effects of climate change and variability. Phil. Trans. R. Soc. B 362, 2351-2365. doi: 10.1098/rstb.2006.1953

Trathan, P. N., Garcia-Borboroglu, P., Boersma, D., Bost, C. A., Crawford, R. J. M., Crossin, G. T., et al. (2015). Pollution, habitat loss, fishing, and climate change as critical threats to penguins. Conserv. Biol. 29, 31-41. doi: 10.1111/cobi.12349

Trivelpiece, W. Z., and Fraser, W. R. (1966). The breeding biology and distribution of Adelie penguins: adaptations to environmental variability. Foundations for ecological research west of the Antarctic Peninsula. Ant. Res. Ser. 70, 273-285. doi: 10.1029/AR070p0273

Vaughan, D. G., Barnes, D. K. A., Fretwell, P. T., and Bingham, R. G. (2011). Potential seaways across west Antarctica Geochem. Geophys. Geosyst. 12:Q10004. doi: 10.1029/2011GC003688

Venables, H. J., Clarke, A., and Meredith, M. P. (2013). Wintertime controls on summer stratification and productivity at the western Antarctic Peninsula. Limnol. Oceanogr. 58, 1035-1047. doi: 10.4319/lo.2013.58.3.1035

Waller, C. L., Overall, A., Fitzcharles, E. M., and Griffiths, H. (2017). First report of Laternula elliptica in the Antarctic intertidal zone. Pol. Biol. 40, 227-230. doi: 10.1007/s00300-016-1941-y

Warwick-Evans, V., Ratcliffe, N., Lowther, A. D., Manco, F., Ireland, L., Clewlow, H. L., et al. (2018). Using habitat models for chinstrap penguins Pygoscelis Antarctica to advise krill fisheries management during the penguin breeding season. Divers. Distrib. 24, 1756-1771. doi: 10.1111/ddi. 12817

Young, B. E., Byers, E., Hammerson, G., Frances, A., Oliver, L., and Treher, A. (2015). Guidelines for Using the NatureServe Climate Change Vulnerability Index. V3.0. Available online at: www.natureserve.org.

Zizzari, Z. V., and Ellers, J. (2014). Rapid shift in thermal resistance between generations through maternal heat exposure. Oikos 123, 1365-1370. doi: 10.1111/oik.01496

Conflict of Interest Statement: The authors declare that the research was conducted in the absence of any commercial or financial relationships that could be construed as a potential conflict of interest.

Copyright (C) 2019 Morley, Barnes and Dunn. This is an open-access article distributed under the terms of the Creative Commons Attribution License (CC BY). The use, distribution or reproduction in other forums is permitted, provided the original author(s) and the copyright owner(s) are credited and that the original publication in this journal is cited, in accordance with accepted academic practice. No use, distribution or reproduction is permitted which does not comply with these terms. 